\title{
Teacher Characteristics and Students' Academic Achievements in Physics in STEM Model Public Secondary schools in Nairobi Metropolitan Kenya
}

\author{
Nelisa Kagendo Mbaka ${ }^{1}$, Shem Mwalw'a ${ }^{2}, \&$ Jacinta Mary Adhiambo ${ }^{3}$ \\ ${ }^{1}$ PhD student at Catholic University of Eastern Africa \\ ${ }^{2,3}$ The Catholic University of Eastern Africa
}

\begin{abstract}
The objective of the study was to assess the influence of teacher characteristics on student's academic achievements in physics in Science Technology Engineering and Mathematics (STEM) model schools in Nairobi Metropolitan region, Kenya. The study used convergent parallel mixed method design. The target population comprised 11principals, 60 teachers and 1120 students with a sample size of 368 (11 principals, 39 teachers and 318 students). The study was anchored on Brunner theory. Proportionate stratified sampling and simple random sampling was used to select students while purposive sampling was used to select teachers of physics and principals. Questionnaires, document analysis guide and interview guide were used to collect data. Descriptive statistics (frequencies and percentages) were used to analyze quantitative data. Thematic and content analysis were used for qualitative data analysis. The study found out that teacher characteristics influence student's academic achievements in physics in STEM model schools. Physics performance depended on the teaching approaches and methods used by the teacher, and mastery of physics content and experience. Moreover, teachers' belief in students enable them to work harder, they encourage and motivate students to perform better in case they post poor grades. The study recommends that teachers strive to be passionate in teaching physics, believe in students' abilities to perform better in physics to work harder when they post poor grades in physics and create a friendly classroom learning environment that is favorable for learning to take place. This will ensure that teachers adopt various integrated STEM learning approaches like problem based, project based and inquiry-based learning while teaching.
\end{abstract}

Key words: Professional Development, Teaching Experience, Teachers' Attitude, Teachers Characteristics, STEM Programme, Student's Academic Achievements

\section{INTRODUCTION}

$\mathrm{S}$ cience, Technology, Engineering and Mathematics (STEM) education is a curriculum based on the idea of educating students in four specific disciplines namely science, technology, engineering and mathematics (STEM) in an interdisciplinary and applied approach. Rather than teach the four disciplines as separate and discrete subjects, STEM integrates them into a cohesive learning paradigm based on real-world applications (Homan, 2014, Rinke, Kinlaw, Gladstone-Brown, \& Cappiello, 2016). STEM education is a very broad term (Baran, Bilici, Mesutoglu, \& Ocak, 2016; Bybee, 2013; Hsu, Lin, \& Yang, 2017). This means definitions and STEM parameters may vary from school to school and depends on the country where it is being applied.

STEM Education was an initiative created by the National Science Foundation (NSF) and was originally called Science, Mathematics, Engineering and Technology (SMET) (White, 2014). This educational initiative was to provide all students with critical thinking skills that would make them creative problem solvers and ultimately more marketable in the workforce. Consequently, many countries have infused STEM in the education curriculum in attempt to prepare learners with these $21^{\text {st }}$ century skills. STEM education was first assimilated by United States mainly to resolve various issues in the workforce as there was a noticeable decline in the number of students joining the various STEM disciplines and specific careers as well as decline in academic performance (NRC, 2011). Many other countries like Kenya incorporated STEM model schools with an aim of responding to similar challenges experienced by USA in performance of STEM related subjects.

STEM education programme was adopted in Kenya in response to the 2015 curriculum reforms to align the Sector to the requirements of the Constitution of Kenya, 2010 and the Kenya Vision 2030 and also in response to the global and national aspirations (Ministry of Education, Science and Technology, 2015). The ministry of education tasked Centre for mathematics, science and technology in East Africa (CEMASTEA) based in Kenya to transform a public secondary school in every County as Model school for STEM. Extra-county schools (two in every county) were selected based on their centrality (located within the county for easy accessibility by other schools), performance, and transformative leadership and with a potential to support a STEM culture. A total of 102 secondary schools were transformed to STEM model schools from September 2016.

The effectiveness of STEM programmes is influenced by different factors. Key among these factors being teacher characteristics. Teacher characteristics is a key determinant of how effective teaching and learning will take place which as a result determines students' academic achievements. Some of the teachers' characteristics include ability to effectively communicate, teacher academic qualifications, teachers 
experience, positive attitude towards students, teachers' commitment, teacher's preparedness, team teaching, being dedicated to teaching physics and having profound subject matter knowledge (Adegbola, 2019). However, the quality of the teacher practices can be improved partly by principals supporting the teachers in upgrading their professional training. Teacher attitude towards teaching is the main determinant of the learner embracing the learning approaches. Some teachers may be at comfort zone and want to continue with the old teacher-centered methods while others may have the training but have negative attitude towards using the student-centered methods this might negatively affect the learner's academic achievement (Rinke, Kinlaw, GladstoneBrown, \& Cappiello, 2016).

Experience helps the teacher to facilitate the transfer of the knowledge effectively. A teacher with many years of teaching might be better in content delivery as they have interacted with content for a long period of time. A study done by Burroughs et al (2019) reviewed a large body of literature in united states on measures of teacher effectiveness, underscoring the diversity of methods by which the general construct of measures associated with higher student achievement: teacher, teacher professional knowledge and teacher provision of opportunity to learn and content coverage. The results were that, when comparing teacher effectiveness (understood as value-added) to student test scores in reading and mathematics, teacher experience was positively related to student mathematics achievement; however, such positive relationships leveled off after teachers had gained two years of teaching experience. Taiwo (1994) as quoted by Mutambuki (2014) challenges this attitude by teachers. An effective teacher is the one who understands his area of specialization and must be able to embrace his subject matter with learner's interest at heart.

In attempt to examine the effect of teacher's characteristics on science student academic performance in Kenya, Langat (2018) established that teachers characteristics like teachers' commitment, teacher's preparedness, team teaching and challenges faced by teachers of physics were found to be influencing academic performance of secondary school students in physics in Bureti Sub County, Kericho County. In addition, Abraham (2020) found that physics teacher characteristics such as academic attainment, teaching experience, teaching methods, utilization of teaching resources, attitude towards teaching physics have a significant influence on academic performance in physics among secondary schools in Tharaka-Nithi County, Kenya. Moreover, Muriithi (2018) found that there is a positive relationship between teacher academic qualification and leaner academic achievement in physics since teachers with high academic qualifications produced better results as compared to teachers of low academic qualifications. Although some studies have shown influence of teacher characteristics on student's academic achievements in physics, the studies focused on secondary schools in general and not specifically STEM model schools. The pertinent question at this point was how does teacher characteristics influence student's academic achievements in physics in STEM model schools in Nairobi Metropolitan region, Kenya?

\section{Statement of Evaluation Purpose}

Science and mathematics subjects at secondary school level in Kenya are among the high-profile subjects. Since independence, the government of Kenya in collaboration with non-state actors has initiated innumerable efforts in trying to improve the quality and performance of science and mathematics disciplines in fulfillment of the Kenyan vision 2030 and sustainable development goals (Kenya vision, 2030), Key among them the STEM model school programme (CEMASTEA, 2017). The government of Kenya through CEMASTEA supplied STEM model schools with learning resources such as robotics kits, cathode ray oscilloscopes, LCD projectors, digital cameras, white-boards, among others. Besides, the Principals have been sensitized on the need of supporting STEM programme and 306 teachers from these schools have undergone training which is done yearly since 2017.

Despite of all these initiatives, studies show that performance of STEM related subjects particularly physics at secondary level in Kenya has been dropping significantly raising an alarm to society. In Nairobi metropolitan region many schools performed poorly in physics in the Kenya Certificate of Secondary Education (KCSE). A baseline survey by the Kenya National Examinations Council (2019) witnessed candidates' alarming failures in science and mathematics in the year 2017. There were very low pass rates recorded in physics, biology and mathematics. Mathematics scored a mean of 32.03 percent, Physics 34.35 percent, Biology 33.5 percent and Chemistry 36.21 percent as compared to languages such as English (57.92 percent), Kiswahili (52.73 percent) and French (63.02 percent).

The pressure to perform and get good grades has resulted to schools turning every opportunity for class work. This pressure has been so much that students have resulted to rote learning and just memorizing facts. Introduction of STEM programme has put a lot of pressure on teachers due timeconsuming learning and teaching approaches as well as increase in student's enrollment. Many studies have shown that teacher characteristics like teacher academic qualifications, teachers experience, positive attitude towards students, teachers' commitment, teacher's preparedness in secondary schools have improved student's academic achievements. However, these studies did not specifically focus STEM model schools. Given the difference in context, the study sought to fill the gap by assessing the influence of teacher characteristics on student's academic achievements in physics in STEM model schools in Nairobi Metropolitan, Kenya. 


\section{Objective of the Study}

The objective of the study was to assess the influence of teacher characteristics on student's academic achievements in physics in STEM model schools in Nairobi Metropolitan Kenya.

\section{LITERATURE REVIEW}

The effectiveness of STEM programmes is influenced by different factors. Key among these factors being teacher characteristics. This section examines how teacher characteristics specifically attitude teacher experience and teacher profession development have affected the effectiveness of STEM programmes. In Poland, faint interest in physics is widely reported in secondary schools and it is blamed on the teaching approach that widely involves textbook reading in the classrooms of which students describe as boring (Ali, 2018). According to McGrath and Hughes (2018), most of the teachers in the school district over rely on the instructional method in the classroom consisting of lectures and textbook reading, which lead to poor understanding of students in the science and math subjects. Consequently, most of the students fail to meet the standard of performance in the STEM subjects. Research has shown that over reliance on lecture instructional strategy has negative effects on students' performance (Edwards, \& Clinton, 2019; Dunn \& Kennedy, 2019). Similarly, Wahono et al (2020) in their study in Eastern Asia observed that in Asia, the teaching methodology is poor as education system is exam-oriented. The education system should be tailored to equip qualified teachers with a set of competencies to facilitate quality learning and cater for national priorities.

Further, studies also noted that the philosophy of teaching focuses mainly on learning and memorization within the teaching and that students practice remembering concepts. This is a pertinent issue that needs to be addressed if STEM education has to see the light of the day. For any introduced educational intervention especially that of STEM, instructors are normally given an induction training. On the same note when applying a specific STEM approach in the classroom, the role of the teacher is essential (McCaslin, 2015). Why teachers are adamant to their teaching strategies to STEM learning approaches spells negative attitude. Teachers have vital role in students learning and understanding. However, these studies may differ when it comes to Kenyan context, hence the need for the current study.

Teachers are arguably professionals with the highest degree of influencing student's academic performance. A study by Ndiku et al (2012) was carried to investigate teacher-related factors associated with performance in mathematics in public day primary schools in Nandi Central district, Kenya. Seventy-four mathematics teachers participated in the study. The study revealed that the majority of mathematics teachers in Nandi Central district public day primary schools were trained with a teaching experience of between 11-20 years. However, they gave an average rating on the mathematics teachers' use of learning resources, teaching methodology, teacher preparation, commitment, and assessment and evaluation. Further, teachers in high performing schools rated the attitudes toward mathematics, teaching methodology, commitment, preparation, and use of learning resources, evaluation and assessment higher than their counterparts in the low performing schools. Sometimes teachers in low performing schools have negative attitude that sciences can only be performed by students who are in high performing national schools.

Teacher attitude towards teaching is the main determinant of the learner embracing the learning approaches. Some teachers may be at comfort zone and want to continue with the old teacher-centered methods while others may have the training but have negative attitude towards using the student-centered methods this might negatively affect the learner's academic achievement. However, this study was only from one body (KNEC) (Muriithi, 2018). There is need for further studies to ascertain the role of a teacher in moderating relationship between STEM learning approaches and academic student's academic achievement in physics in secondary schools in Kenya.

The evolved $21^{\text {st }}$ century classroom is a productive environment in which students can develop the skills they will require in the workplace and teachers are facilitators of their learning (Saxena , 2013). In order to prepare physics literate citizens, the 21 st century classrooms need to be structured so that mathematics and science subjects can be learned with understanding. Muriithi (2018) examined the effect of teacher characteristics on learner academic achievement in physics in Kenyan secondary schools. The study established that there is a positive relationship between teacher academic qualification and leaner academic achievement in physics. Teachers with high academic qualifications produced better results in physics as compared to teachers of low academic qualifications. Moreover, teachers with both academic and pedagogical qualifications produced better scores in physics among students than those without pedagogical qualifications.

STEM activities in the classroom endeavor to improve the quality of the learning process (Meyrick, 2011), as well as learning outcomes (Cedefop, 2017). However, the activities themselves may not improve students' learning outcomes. These activities should be accompanied by a dedicated teacher applying the appropriate pedagogy to interest learners in what they are doing which may produce quality learning outcomes. Nduku (2017) investigated the influence of SMASSE project on the performance of chemistry in Kenya certificate of secondary education (KCSE). The findings showed that teachers had not changed teaching approaches despite training of science teachers. The results further showed that they did not prepare the Activity, Students Centred Approach, Experiment, Improvise, Plan, Do, See and Improve) (ASEI PDSI) lesson plans and thus the academic performance was low. Negative attitude towards mathematics and science by teachers eventually get to the learners. 
STEM approaches require relatively a small number of students. The student's teacher ratio could be too high in such a way that teachers may resolve using lecture method because they have too many students per lesson. The training of teachers is an endeavor that is ought to bring positive changes in their pedagogical approaches. Mukekhe (2019) contends that training of physics teachers should focus more on content. Nevertheless, teachers should not be put merely into a listening mode during training but they should participate actively in the training sessions and perform hands on activities which in turn they apply in the classroom scenario. Kariuki, Kiprop \& Thinguri_(2014) did an evaluation of the effectiveness of SMASSE program in performance of science and mathematics in primary schools in Kenya using documented data. Results showed that majority of the teachers had not adopted the activity, Student-centered, Experiments and Improvisation (ASEI) and Plan, Do, See and Improve (PDSI) approaches leading to poor results in the two subjects. The teaching and learning process therefore became a teachercentered affair, being mainly knowledge based "talk and chalk" thing with little or no active leaner involvement. The educational experience for students is impacted to a great extent by the quality and effectiveness of teachers (Nathan, Tran, Atwood, Prevost, \& Phelps, 2010).

\section{Conceptual Framework}

The conceptual framework in Figure 1, depicts the relationship between the independent variable (Teacher characteristics) and the dependent variable (student's academic achievements in physics in STEM model schools in Nairobi Metropolitan region, Kenya).

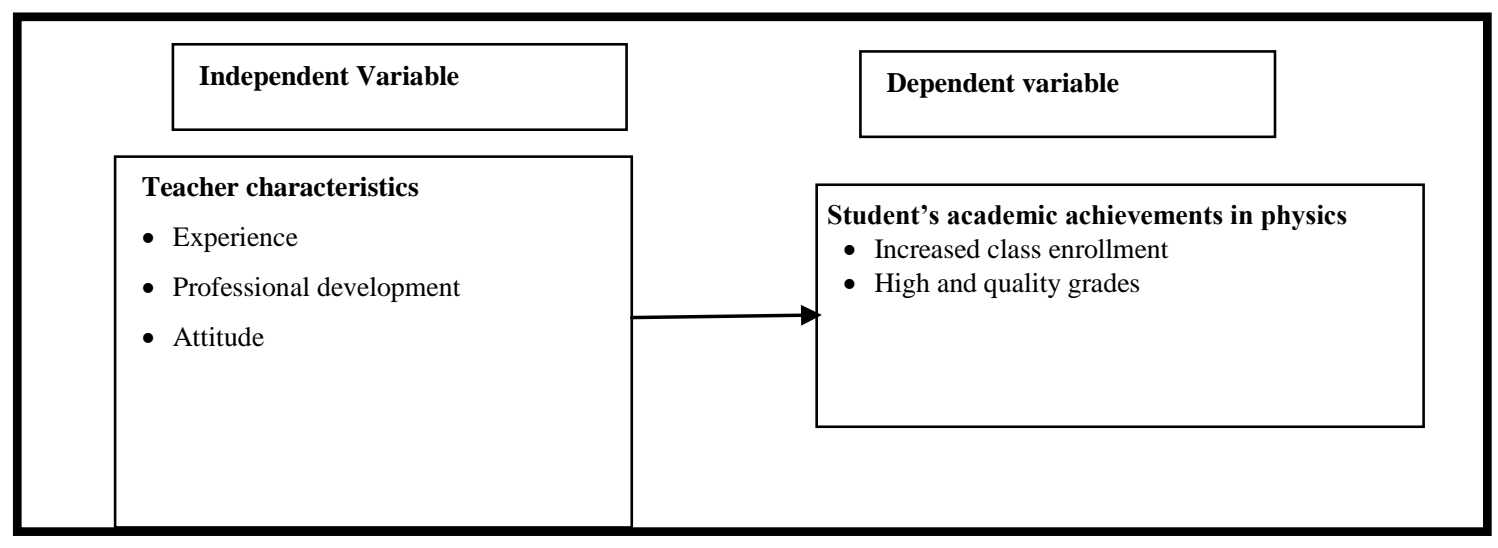

Figure 1: Conceptual Framework

\section{RESEARCH DESIGN AND METHODOLOGY}

This study employed a convergent parallel mixed-methods design. This is an approach to inquiry that combines both qualitative and quantitative methods concurrently, prioritizing both methods almost equally (Creswell \& Clark, 2017, and Creswell, 2014). In this case, the quantitative and qualitative methods complement each other, and provide for the triangulation of findings, hence greater validity of the emerging inferences. Whereas the quantitative approach gave more general understanding of integrated STEM program, the qualitative provided a detailed and in-depth understanding of the phenomena at hand.

The target population consisted of 11 Principals, 110 teachers of physics and who had undergone training on integrated STEM programme and 1100 Form four Physics students. The reason for using form four is that they have been taught by STEM trained teachers for a longer period. The study used both probability and non-probability sampling techniques to draw the sample. Stratified and purposive sampling techniques were used to sample 297 students, 60 teachers and 11 principals respectively from the selected schools.
To collect data, questionnaires, Document Analysis Guide (DAG) and interview guide were used. Before conducting the actual study in the sampled STEM model schools, theevaluator obtained a letter of clearance from the department of Post Graduate Studies in Education, at the Catholic University of Eastern Africa. Permits to collect data were obtained from the National Council for Science Technology and Innovation (NACOSTI) and Regional Director of Education, Nairobi office. The collected data were analyzed using descriptive statistics mainly; counts, percentages, frequencies and mean. Following Creswell (2012) and Khan (2014), qualitative data analysis involved data logging (data documentation) which is the next level after data collection, anecdotes (streamlining data log), vignette (narrative or story investigation on the interpretation of the person knowledge or circumstances that the researcher describes), data coding and then tagging the data related according to specific themes.

\section{FINDINGS AND DISCUSSIONS}

The section deals with the presentation, interpretation and discussion of the findings on the objective of the study. To begin with, the data was collected through questionnaire from 
teachers and students while interview guide solicited data from the principals. The response rate is as shown in Table 1.

Table 1: Instrument Return Rate

\begin{tabular}{|c|c|c|c|}
\hline & Sampled & Returned & $\begin{array}{c}\text { Return } \\
\text { rate } \\
(\boldsymbol{\%})\end{array}$ \\
\hline Students & 297 & 218 & 73.4 \\
\hline Teachers & 60 & 39 & 65.0 \\
\hline Principals & 11 & 9 & 81.8 \\
\hline Total & $\mathbf{3 6 8}$ & $\mathbf{2 6 6}$ & \\
\hline
\end{tabular}

Source: Evaluators 2021

From the findings in Table 1, the evaluator distributed 297 questionnaires to students out of which only 218 were returned and this gave a response rate of $73.4 \%$. Moreover, the evaluator distributed 60 questionnaires to students out of which only 39 were returned and this gave a response rate of $65 \%$. Finally, the evaluator targeted 11 principals for interviews but only 9 Out of 11 were interviewed representing a response rate of $81.8 \% \%$ resulting to a total of 266 participants with a response rate of $72.3 \%$. This was adequate for analysis as per Bryman (2017) who argues that a return rate that is more than $50 \%$ is considered to be adequate for statistical analysis.

Influence of Teacher Characteristics on Student's Academic Achievements

The main objective of this study was to establish the influence of teacher characteristics on student's academic achievements in physics in STEM model schools in Nairobi Metropolitan region, Kenya. Teacher characteristics are a key determinant of how effective teaching and learning take place which as a result determines students' academic achievements. Therefore, the students were asked to indicate how frequently the teachers portray various behaviors in their school using 15likert scale where 1 is always (A), 2 is often $(\mathrm{O}), 3$ is sometimes $(\mathrm{S}), 4$ is rarely $(\mathrm{R})$ and 5 is Not at all $(\mathrm{N})$. The findings are illustrated in Table 2.

Table 2: Students' responses on how frequently the teachers portray various behaviours

\begin{tabular}{|c|c|c|c|c|c|c|c|}
\hline Statement & $\mathbf{A}$ & $\mathbf{O}$ & $\mathbf{S}$ & $\mathbf{R}$ & $\mathbf{N}$ & Mean & Std. \\
\hline & f $(\%)$ & f $(\%)$ & f $(\%)$ & f $(\%)$ & $\mathbf{f}(\%)$ & & \\
\hline $\begin{array}{l}\text { Our teacher mostly uses lecture method to } \\
\text { teach physics subject }\end{array}$ & $30(13.8)$ & $49(22.5)$ & $80(36.7)$ & 25 (11.5) & 34 (15.6) & 2.93 & 1.23 \\
\hline $\begin{array}{l}\text { My teacher uses various teaching methods and } \\
\text { we enjoy learning physics }\end{array}$ & $66(30.3)$ & $30(13.8)$ & $67(30.7)$ & 23 (10.6) & $32(14.7)$ & 2.66 & 1.39 \\
\hline $\begin{array}{l}\text { I like my physics teacher because he/she } \\
\text { explains physics content with ease and } \\
\text { everybody understands }\end{array}$ & 39 (17.9) & 34 (15.6) & $92(42.2)$ & $28(12.8)$ & 25 (11.5) & 2.84 & 1.20 \\
\hline $\begin{array}{l}\text { In this school, my teacher believes all students } \\
\text { can learn physics }\end{array}$ & $64(29.4)$ & $18(8.3)$ & $55(25.2)$ & $31(14.2)$ & $50(22.9)$ & 2.93 & 1.52 \\
\hline $\begin{array}{l}\text { In this school, if you do poorly on a physics } \\
\text { test, the teacher encourages you to do better } \\
\text { next time. }\end{array}$ & $59(27.1)$ & $20(9.2)$ & $59(27.1)$ & 32 (14.7) & $48(22)$ & 2.95 & 1.49 \\
\hline
\end{tabular}

Source: Evaluators 2021

From the findings in Table 2, 36.7\% of the students indicated that physics teachers sometimes teach physics through lecture method and $30.7 \%$ of the students opined that their teachers use of several ways of teaching making learning physics enjoyable These findings imply that teachers sometimes use lecturer method in teaching although the STEM approved teaching methods are inquiry based, problem solving to mention but a few that would engage students for mastery of skills and content. It was observed that sometimes various methods are incorporated in physics teaching which make it enjoyable for students. The means for the statements were 2.93 and 2.66 respectively. These imply that teachers sometimes use lecturer method in teaching, although sometimes various methods are incorporated in physics teaching which make it enjoyable for students. Burroughs, et al., (2019) note that diversity of methods by which the general construct of measures associated with higher student achievement: teacher professional knowledge and teacher provision of opportunity to learn and content coverage.
Moreover, $42.2 \%$ of the students reported that their physics teachers explain physics content with ease and everybody understands. In addition, $29.4 \%$ of the students indicated that their teachers always believe that all students can learn physics. Teachers' belief in the students is a motivating factor towards good performance. The mean scores for the statements were 2.84 and 2.93. This implies that students in targeted schools like physics because teachers explain physics content with ease and everybody understands and teachers believe in students' abilities to learn. McCaslin (2015) notes that teachers have vital role in students learning and understanding.

Furthermore, $27.1 \%$ of the students indicated that if they do poorly on a physics test, the teacher always encourages them to do better next time. This shows that physics teachers are very supportive of the students irrespective of their performance. The mean for the statement was 2.95 and this shows that physics teachers are very supportive of the students irrespective of their performance. This is not different from 
the findings of PISA (2016) that where teachers used cognitive-activation strategies in mathematics, which encourage students to think and reflect, use their own procedures to solve a problem, explore multiple solutions, learn from mistakes, ask for explanations and apply learning in different contexts, improved performance in mathematics.
The Physics teachers were further asked to indicate how frequently they portray various behaviors in their school using 1-5likert scale where 1 is always (A), 2 is often $(\mathrm{O}), 3$ is sometimes $(\mathrm{S}), 4$ is rarely $(\mathrm{R})$ and 5 is Not at all $(\mathrm{N})$. The findings are illustrated in Table 3.

Table 3: Teachers' responses on how frequently they portray various behaviours

\begin{tabular}{|c|c|c|c|c|c|c|c|}
\hline & $\mathbf{A}$ & $\mathbf{O}$ & $\mathbf{S}$ & $\mathbf{R}$ & $\mathbf{N}$ & Mean & Std. \\
\hline & $f(\%)$ & $f(\%)$ & $f(\%)$ & $f(\%)$ & $\mathbf{f}(\%)$ & & \\
\hline $\begin{array}{l}\text { Physics performance is low because teachers mostly } \\
\text { use lecture method to teach physics content }\end{array}$ & $2(5.1)$ & $9(23.1)$ & $13(33.3)$ & $12(30.8)$ & $3(7.7)$ & 3.13 & 1.03 \\
\hline $\begin{array}{l}\text { I post quality grades in physics because I have } \\
\text { extensive knowledge and experience in using } \\
\text { different teaching approaches like Student-Centered } \\
\text { and Inquiry-Based Learning. }\end{array}$ & $13(33.3)$ & $18(46.2)$ & $6(15.4)$ & $2(5.1)$ & $\begin{array}{c}0 \\
(0)\end{array}$ & 1.92 & 0.84 \\
\hline $\begin{array}{l}\text { I believe every student can learn and perform better } \\
\text { in physics }\end{array}$ & $25(64.1)$ & $0(0)$ & $8(20.5)$ & $3(7.7)$ & $3(7.7)$ & 1.95 & 1.38 \\
\hline $\begin{array}{l}\text { Even if students perform poorly on a physics test, I } \\
\text { encourage them to do better next time. }\end{array}$ & $25(64.1)$ & $0(0)$ & $3(7.7)$ & $8(20.5)$ & $3(7.7)$ & 2.08 & 1.51 \\
\hline $\begin{array}{c}\text { My physics students perform exceptionally well } \\
\text { because I understand physics content and am usually } \\
\text { passionate when teaching }\end{array}$ & $10(25.6)$ & $15(38.5)$ & $9(23.1)$ & $5(12.8)$ & $\begin{array}{c}0 \\
(0)\end{array}$ & 2.23 & 0.99 \\
\hline
\end{tabular}

Source: Evaluators 2021

From the findings in Table 3, 33.3\% of the teachers indicated that physics performance is sometimes low because they use lecture method to teach physics content. The mean scores the statements were 3.13 which implied that low performance in physics cannot entirely be linked to use of lecture method in physics teaching. The findings are consistent with Cassandra (2014) who notes that methods of teaching commonly employed during the training of physics teachers has for a long time been traditional lecture. This is done probably with the aim of covering a wide range of content and easy syllabus coverage.

The table also shows that $46.2 \%$ of the teachers reported that they often post quality grades in physics because they have extensive knowledge and experience in using different teaching approaches in teaching physics like student-centered and inquiry-based learning. This means that low performance in physics cannot entirely be linked to use of lecture method in physics teaching given that some schools post quality grades in physics. Maguswi (2011) found that lack of qualified teachers of Physics had a significant contribution to performance of the subject.

It is also observed that $64.1 \%$ of the teachers said that they always believe that every student can learn and perform better in physics. Furthermore, $64.1 \%$ of the teachers responded that even if students perform poorly in a physics test, they always encourage them to do better next time. The findings imply that teachers believe in students' ability to perform better in physics and that is why they encourage them to work harder to overcome the difficulties experienced in learning physics.
Inda (2013) and Armstrong (2015) argue that teacher's characteristics impacts positively on student academic performance in science subjects.

In the same development, $38.5 \%$ of the teachers indicated that their physics students often perform exceptionally well because they understand physics content and am usually passionate when teaching. This means that such performance is as a result of students' comprehension of physics content, dedication of the physics teachers and the use of learner centred method of teaching. Boston et al (2015) argue that the teachers with strong beliefs in using inquiry-based instructional approach motivate students. The belief and interest in utilizing student-centred methods is not about the experience or number of years a teacher has spent in teaching but revolves around the commitment and dedication to add value to the learner.

Principal's interviews on the extent to which teacher qualification, experience and teacher attitude affect student academic achievement coll

aborated with that of the other participants. P1, P3, P5, P7, P8 and P9 explained teachers' qualification and experience greatly affects students' performance. The teachers need the knowledge of science so that they implement STEM programme effectively. In support of this, some of the principals shared:

From my observation, you are able to differentiate teachers who normally have career progression from teachers who do not. At least we sponsor 4 STEM 
teachers annually for training and I have seen this impact on the students' performance. On the other hand, majority of the teachers have an experience of not less than 10 years. With long years of teaching, a teacher has the content in their finger tips and knows how to vary the teaching methods. This perhaps has accelerated the good performance of our physics students (Principal 7, $9^{\text {th }}$ August, 2021).

Another one said;

You know young and inexperienced teachers do not have much content and confident in them. They cram content before going to class. STEM programme requires calm mind so that one is able to think through the concept delivered to students. Even though young teachers may be more curious than experienced teachers, they may be lacking the skills and tactics required for implementation of STEM programme (Principal 8, $10^{\text {th }}$ August, 2021).

The two excerpts show the need develop physics teachers so that they are kept abreast with the approaches that have been researched and tested to be effective for STEM subjects. Rote learning strategy has no place in the STEM subjects and so all the reason why teachers should be encouraged to use more the learner centred approaches of inquiry based, problem solving, experiments and project based to mention but a few.

Attitude plays a great role in the teaching and learning of any subject. On the question of the attitude of teachers towards teaching and learning of physics, Principals 3, 5 and 9 pointed that majority of the teachers have positive attitude. Teachers, who have positive attitude and interest in teaching, believe in their students and they perform well. Those teachers who have negative attitude and have less interest in what they are teaching of course teach casually and their students end up performing dismally. In addition, one of the principals, pointed that

Sometimes I think we unfairly blame teachers for the poor grades posted by students forgetting that there are many factors in play such as Students' attitude towards the teacher and/or subject, syllabus coverage because exams are tested from the syllabus. Science teachers have heavy workload at times making STEM learning approaches almost impossible given that this teacher has the second subject to teach other than physics (Principal 9, $12^{\text {th }}$ August, 2021).

Teachers' attitude plays a key role in teaching and enhancing students' performance. This because teachers who have positive attitude and interest in teaching, believe in their students while those with negative attitude and have less interest, teach as if simply meeting the obligation and their students end up performing dismally. Saxena (2013) argues that teachers' attitude is the main determinant of the learner embracing the learning approaches. Some teachers may be at comfort zone and want to continue with the old teachercentred methods while others may have the training but have negative attitude towards using the student-centred methods. This might negatively affect the learner's academic achievement. Sharma (2017) noted that for meaningful learning to be achieved, teaching should not just be merely for the sake of doing it as per the employers' requirements, but should be done with the aim of transforming students psychologically, cognitively and behaviorally. Huziak-Clark, Sondergeld, van Staaden, Knaggs and Bullerjahn (2015) also note that STEM education programmes impact on cognitive student's outcomes. This is mainly based on teacher techniques, single STEM teacher or team teaching.

\section{Correlation Analysis}

The study conducted correlation analysis to establish the relationship between teacher characteristics and student's academic achievements in physics in STEM model schools in Nairobi Metropolitan region, Kenya. The findings are shown in Table 4.

Table 4: Correlations Results

\begin{tabular}{|c|c|c|c|}
\hline & & $\begin{array}{c}\text { Teacher } \\
\text { characteristics }\end{array}$ & $\begin{array}{c}\text { Students' } \\
\text { achievements }\end{array}$ \\
\hline \multirow{2}{*}{$\begin{array}{c}\text { Teacher } \\
\text { characteristics }\end{array}$} & $\begin{array}{c}\text { Pearson } \\
\text { Correlation }\end{array}$ & 1 & $.781^{* *}$ \\
\hline & $\begin{array}{l}\text { Sig. (2- } \\
\text { tailed) }\end{array}$ & & .011 \\
\hline \multirow{2}{*}{$\begin{array}{c}\text { Students' } \\
\text { achievements }\end{array}$} & $\begin{array}{c}\text { Pearson } \\
\text { Correlation } \\
\end{array}$ & $.781^{* *}$ & 1 \\
\hline & $\begin{array}{l}\text { Sig. (2- } \\
\text { tailed) }\end{array}$ & .011 & \\
\hline
\end{tabular}

As per the results in Table 13, the $r=0.781$ and $p$-value $=0.011$. Since the p-value was less than 0.05 , the study established that there is a positive and significant relationship between teacher characteristics on students' achievements in physics in the study sample. The findings concur with Inda (2013) who established that teacher's characteristics impacts positively on student academic performance in science subjects such as physics.

\section{Teachers Professional Documents and Appraisal Record}

The use of Document Analysis Guide enabled the evaluators in collecting data and focus on relevant information that could shed light on the teacher's development and appraisal in relation to STEM subjects. The evaluators perused through the lesson plans to confirm their availability, authentication and effectiveness in enhancing STEM programme implementation. The findings are illustrated in Table 5 . 
Table 5: Assessment of professional documents of teachers by principals

\begin{tabular}{|c|c|c|c|}
\hline Teaching standards & Performance targets & $\begin{array}{l}\text { No of schools } \\
\text { Remarks }\end{array}$ & Remarks \\
\hline \multirow{2}{*}{ Lesson plan } & $\begin{array}{l}\text { The teacher goes to class with a prepared lesson } \\
\text { plan }\end{array}$ & 6 & $\begin{array}{l}\text { In all the schools, teachers had up to date lesson } \\
\text { plans and in line with schemes of work }\end{array}$ \\
\hline & Schemes of work is appropriate and updated & 6 & $\begin{array}{l}\text { In all the schools, teachers had schemes of work } \\
\text { which were well updated }\end{array}$ \\
\hline \multirow{8}{*}{$\begin{array}{l}\text { Professional } \\
\text { knowledge and } \\
\text { application }\end{array}$} & Previous knowledge linked to new topic. & 5 & $\begin{array}{l}\text { Five schools having teachers helping students in } \\
\text { linking the previous knowledge acquired from } \\
\text { previous topics and linking ideas from other science } \\
\text { subjects }\end{array}$ \\
\hline & Introduction is clear and interesting. & 5 & $\begin{array}{l}\text { Five schools having teachers introducing a topic or } \\
\text { subtopic clearly and in an interesting manner }\end{array}$ \\
\hline & $\begin{array}{l}\text { Learners are able to express prior experiences } \\
\text { based on the content learned. }\end{array}$ & 6 & $\begin{array}{l}6 \text { schools having learners able to express prior } \\
\text { experiences learnt in physics and borrowing ideas } \\
\text { from other sciences }\end{array}$ \\
\hline & $\begin{array}{c}\text { Lesson allows learners to practice skills like } \\
\text { observation, measuring identifying variables. } 7 \\
\text { Learners are able to give their own } \\
\text { forecasts/predictions }\end{array}$ & 7 & $\begin{array}{l}7 \text { schools with learners able to put the theoretical } \\
\text { skills into practice }\end{array}$ \\
\hline & Lesson encourages active learner participation. & 7 & $\begin{array}{c}7 \text { schools admitted that STEM lessons encouraged } \\
\text { active learner participation }\end{array}$ \\
\hline & $\begin{array}{l}\text { The lesson is focused more on activities than on } \\
\text { content (i.e. is the lesson Learner- centered) }\end{array}$ & 6 & 4 schools agreed that lesson is students $=$ centered \\
\hline & Classroom management and organisation & 8 & $\begin{array}{l}8 \text { schools agreed that classroom management was } \\
\text { good }\end{array}$ \\
\hline & Utilization of physics laboratory facilities & 9 & $\begin{array}{c}\text { All } 9 \text { schools listed that both teachers and students } \\
\text { utilize physics laboratory facilities }\end{array}$ \\
\hline
\end{tabular}

Source: Evaluators 2021

From the document analysis of lesson plans, the evaluators noted that in 6 out of 9 schools, teachers had up to date lesson plans and in line with schemes of work. Lesson plans enable teachers to function more effectively in the classroom by giving a detailed outline that they adhere to during each class as it determines what the students will learn, how the lesson will be taught as well as how learning will be evaluated. The teachers in those 6 schools also had schemes of work which were well updated. Schemes of work are important as they help teachers plan and sequence their lessons in advance and this ensures that all course content is taught leading to effective syllabus coverage. Appraising teacher's professional knowledge ensures that teachers are knowledgeable in their subject area and implement their teaching effectively. Teachers Service Commission report (2018), articulates that teacher's appraisal is effective as it has seen more teamwork amongst teachers, better preparedness and students' higher academic achievements.

Teachers in five schools help students to link the previous knowledge acquired from previous topics with other science subjects. In addition, the evaluators found out that in six schools' learners are able to express prior experiences learnt in physics borrowing ideas from other sciences. Others are able to put the theoretical skills into practice because STEM lessons encouraged active learner participation. Such a practice is based on Constructivist's theorists Brunner (1961), who postulated that the purpose of education is not to impart knowledge, but instead to facilitate a child's thinking and problem-solving skills which can then be transferred to a range of situations. Such learner-centered teaching and learning approaches play a great role in science subjects because they make students interested in what they are learning resulting to better academic performance as established by Gichuhi (2013).

\section{CONCLUSIONS}

The study concluded that teacher characteristics: teachers' attitude, teaching experience and professional development in STEM subjects teaching influence student's academic achievements in physics in STEM model schools in Nairobi Metropolitan region, Kenya. Physics performance depend on the method of teaching used by the teacher, mastery of knowledge, teachers' belief in learners, learner motivation by the teacher and teachers' experience in using different teaching approaches in teaching physics. Performance of physics could be improved if the principals closely monitor the implementation of the learner centred teaching approaches and methods as advanced by the proponents of STEM subjects. However, this can only happen if the teachers are creative and passionate about their teaching subject.

\section{RECOMMENDATIONS}

The study recommends that teachers should continuously strive to create a friendly classroom learning environment that is favorable for teaching and learning physics. This will improve student-teacher relationship which improves students trust on teachers' capabilities. Improving students' relationships with teachers ensures that students are engaged fully in learning and this enhances their academic achievement in physics.

The study also recommends that teachers should be passionate in teaching physics to adopt various integrated STEM learning 
approaches such as problem based, project based and inquirybased learning. This gives students the opportunities to be innovative and creative. The transfer of learning can be observed if students use broken apparatus such as television, radios and computers during physics club time.

\section{REFERENCES}

[1] Abraham, K. S. (2020). Influence Of Teachers' and Learners' characteristics on Enrolment and Academic Performance in Physics Among Secondary Schools In Tharaka-Nithi County, Kenya (Doctoral dissertation, Kenyatta University).

[2] Adegbola, F. F. (2019). Teachers' pedagogical competence as determinants of student's attitude towards basic science in South West Nigeria. Educational Research and Reviews, 14(18), 655660 .

[3] Ali, T. (2018). Raising teachers' voices: an in-depth qualitative inquiry into teachers' working conditions and professional development needs in Khyber Pakhtunkhwa, a province of Pakistan. Teacher Development, 22(1), 78-104.

[4] Armstrong, P. (2015). Teacher characteristics and student performance: An analysis using hierarchical linear modelling. South African Journal of Childhood Education, 5(2), 123-145.

[5] Baran, E., Bilici, S. C., Mesutoglu, C., \& Ocak, C. (2016). Moving STEM beyond schools: Students' perceptions about an out-ofschool STEM education program. International Journal of Education in Mathematics, Science and Technology, 4(1), 9-19.

[6] Boston, M., Jerrim, J., Oliver, M., \& Sims, S. (2015). The relationship between inquiry-based teaching and students' achievement. New evidence from a longitudinal PISA study in England. Learning and Instruction, 21), 101-310.

[7] Brunner, K. (1961). A schema for the supply theory of money. International Economic Review, 2(1), 79-109.

[8] Bryman, A. (2017). Quantitative and qualitative research: further reflections on their integration. In Mixing methods: Qualitative and quantitative research (pp. 57-78). Routledge.

[9] Burroughs, N., Gardner, J., Lee, Y., Guo, S., Touitou, I., Jansen, K., \& Schmidt, W. (2019). A review of the literature on teacher effectiveness and student outcomes. Teaching for excellence and equity, 7-17.

[10] Bybee, R. W. (2013). Advancing STEM education: A 2020 vision. Technology and Engineering Teacher, 70(1), 30-35.

[11] Cassandra, H. (2014). Games as an interactive classroom technique: Perceptions of corporate trainers, college instructors and students. International Journal of Teaching and Learning in Higher Education, 19(1), 53-63

[12] Cedefop, T., (2017). Defining, writing and applying learning outcomes: A European handbook. Luxembourg: European Centre for the Development of Vocational Training

[13] CEMASTEA. (2017). A Report on the Baseline Study for Science, Technology, Engineering, and Mathematics Model Schools in Kenya. Nairobi: Act Press.

[14] Creswell, J. (2012). Best practices in mixed methods for qualityof-life research. Quality of life Research, 21(3), 377-380.

[15] Creswell, J. W. (2014). Qualitative, Quantitative and Mixed Methods Approaches. Sage Publications.

[16] Creswell, J. W., \& Clark, V. L. P. (2017). Designing and conducting mixed methods research. Sage publications.

[17] Dunn, T. J., \& Kennedy, M. (2019). Technology Enhanced Learning in higher education; motivations, engagement and academic achievement. Computers \& Education, 137, 104-113.

[18] Edwards, M. R., \& Clinton, M. E. (2019). A study exploring the impact of lecture capture availability and lecture capture usage on student attendance and attainment. Higher Education, 77(3), 403421.

[19] Gichuhi, M. (2013). Towards learner centered pedagogies by teacher educators in Kenya: A study of Kericho Teachers' Training College. International Journal of Asian Social Science, 3(1), 255-265.
[20] Homan, O. (2014). Evaluation of strengthening mathematics and science Education programme in secondary schools in BungomaCentral Sub-County, Bungoma County Kenya (MA dissertation, Mount Kenya University).

[21] Hsu, Q., Lin, E., \& Yang, T. (2017). Using inquiry-based strategies for enhancing students' STEM Education Learning. Journal of Education in Science Environment and Health, 4(1), 110-117.

[22] Huziak-Clark, T., Sondergeld, T., van Staaden, M., Knaggs, C., \&Bullerjahn, A. (2015). Assessing the Impact of a ResearchBased STEM Programme on STEM Majors' Attitudes and Beliefs. School Science and Mathematics, 115(5), 226-236.

[23] Inda, A. N. (2013). Influence Of Teacher's Characteristics on Effective Use of Inquiry Based Approach in Teaching Science in Preschools in Kuja Zone, Rongo District (Doctoral dissertation, University of Nairobi)

[24] Kenya National Examinations Council (2019). National Examinations Performance Report. Nairobi: KNEC Publications

[25] Kenya Vision (2030). Kenyan Vision 2030 and Sustainable Development Goals. Nairobi: Act Press

[26] Khan, T. H. (2014). Living with transformation: Self-built houses in the city of Dhaka (Vol. 1): Springer

[27] Langat, K. (2018). Teacher factors influencing Academic Performance of secondary school students in Physics: A study of secondary schools in Bureti Sub County, Kericho CountyKenya (Doctoral dissertation, Moi University).

[28] Maguswi, B.V. (2011). Factors contributing to under achievement of Zambian female Students in O-level Physics examinations. A case of selected high Schools in Central Province. (A Master's Thesis, University of Zambia).

[29] McCaslin, S. D. (2015). The influence of stem initiative programs for middle and high school students on female STEM college majors (Unpublished doctoral dissertation). Capella University, Minnesota, US.

[30] McGrath, A. L., \& Hughes, M. T. (2018). Students with learning disabilities in inquiry-based science classrooms: A cross-case analysis. Learning Disability Quarterly, 41(3), 131-143.

[31] Meyrick, K. M. (2011). How STEM education improves student learning. Meridian K-12 School Computer Technologies Journal, 14(1), 1-6.

[32] Ministry of Education, Science and Technology (2015). STEM Education Programme Report. Nairobi

[33] Mukekhe, M. S. (2019). Perspectives on Relevance of Physics Teacher Education Programmes in Relation to Pedagogic Skills of Student Teachers in Public Universities in Kenya (Doctoral dissertation, Maseno University).

[34] Muriithi, E. M. P. (2018). Effect of teacher characteristics on learner academic achievement in physics in Kenyan secondary schools. International Journal of Education and Research, 6(3), 165-178.

[35] Mutambuki, E. K. (2014). The effect of SMASSE project on performance of mathematics in secondary schools in Kitui Central District, Kitui County, Kenya (Masters Project Thesis, University of Nairobi)

[36] Nathan, M. J., Tran, N. A., Atwood, A. P., \& Phelps, L. A. (2010). Beliefs and expectations about engineering preparation exhibited by high school STEM teachers. Journal of Engineering Education, 99(4), 409-426

[37] Ndiku, L. N., Role, E., Too, J. K., \& Kiplagat, P. (2012). Evaluation of teacher factors associated with mathematics performance in primary schools in Kenya. International Journal of Scientific Research in Education, 5(1), 47-62

[38] Nduku. C. J. (2017). The influence of SMASSE project on the performance of chemistry in Kenya certificate of secondary education (KCSE). (Master's Thesis, University of Nairobi)

[39] NRC. (2011). Successful K-12 STEM education: Identifying effective approaches in science, technology, engineering, and mathematics. National Academies Press.

[40] PISA (2016). PISA 2015 results (Volume I). Excellence and equity in education. Sage Publications 
[41] Rinke, C. R., Gladstone-Brown, W., Kinlaw, C. R., \& Cappiello, J. (2016). Characterizing STEM teacher education: Affordances and constraints of explicit STEM preparation for elementary teachers. School Science and Mathematics, 116(6), 300-309.

[42] Saxena, A. K. (2013). Problem-based learning research in anesthesia teaching: current status and future perspective. Anesthesiology research and practice, 2(1), 1-7.

[43] Sharma, G. (2017). Enhancing students' engagement: Report of a 3 -year intervention with middle school teachers. American Educational Research Journal, 51(6), 1195-1226.

[44] Taiwo, S. N. (1994). Training teachers for integrated science in Nigerian secondary schools (Doctoral dissertation, Institute of Education, University of London).

[45] Teachers Service Commission Report (2018). Teachers Service Commission Report. TSC: Nairobi.

[46] Wahono, B., Lin, P. L., \& Chang, C. Y. (2020). Evidence of STEM enactment effectiveness in Asian student learning outcomes. International Journal of STEM Education, 7(1), 1-18.

[47] White, H. (2014). Metahistory: The historical imagination in nineteenth-century Europe. JHU Press. 